\title{
Cefoperazone with Antacid, Metal Complexation studied by Spectrophotometrically and Exploration of Antimicrobial Activity, In-Vitro Investigation
}

\author{
Joushan Ara*, Syeda Ridita Sharif, Farjana Nawrin, and Md Shahidul Islam \\ Department of pharmacy, University of Science and Technology Chittagong (USTC), Chattogram, Bangladesh
}

Corresponding author: Joushan Ara, Lecturer, Department of Pharmacy, University of Science \& Technology Chittagong (USTC), Chattogram, Bangladesh

\section{ARTICLE INFO}

Received: 幽 October 09, 2020

Published: October 20, 2020

Citation: Joushan Ara, Syeda Ridita Sharif, Farjana Nawrin, Md Shahidul Islam. Cefoperazone with Antacid, Metal Complexation studied by Spectrophotometrically and Exploration of Antimicrobial Activity, In-Vitro Investigation. Biomed J Sci \& Tech Res 31(2)-2020. BJSTR. MS.ID.005081.

Keywords: Cefoperazone; Spectrophotometry; Complexation; Job's Plot; Antimicrobial activity

\section{ABSTRACT}

Cefoperazone as a Cefoperazone sodium is a semisynthetic broad-spectrum cephalosporin antibiotic for which is used as a parenteral drug. Cefoperazone is quite effective against a wide variety of gram positive and gram-negative organisms including staphylococcus, Enterobacter, streptococcus, klebsiella and salmonella species. Cefoperazone is widely used in the treatment of Urinary tract infections, pelvic inflammatory diseases, respiratory tract infections etc. The principal purpose of present follow a line of investigation was to explore in vitro communications of Cefoperazone with crucial metal salt furthermore antacid to settle on the bioavailability in view of antimicrobial movement of Cefoperazone following drug metal communications at the pH7.4. Cefoperazone is one of the cephalosporin drugs to is exercised to treat numerous different sorts of infections originated by bacteria. Since the existence of compelling the ligand may influence bioavailability of metal in blood and tissues, for that reason with the intention of study the handy interaction of the Cefoperazone with vital elements in attendance in the body. Cefoperazone has been related with $\mathrm{Zn}, \mathrm{Mg}$ as an in-vitro examination. Besides, the anti-microbial movement of drug along with the complexes was resolved. It has scrutinized that Cefoperazone interrelates with metal and antacid on the pH 7.4 by plotting various UV spectrophotometric methods. This examine authenticates that there was the interaction between Cefoperazone and metal, antacid which was authenticated by job's plot technique furthermore by antimicrobial exploration. This was authenticated that region of inhibition of Cefoperazone with Metal in addition to antacid condensed from $16 \mathrm{~mm}$ to $14 \mathrm{~mm}$ and $13 \mathrm{~mm}$ correspondingly. The typical Cefoperazone disk also checked in opposition to Staphylococcus aureus.

\section{Introduction}

Cefoperazone sodium is a third-generation semisynthetic antibiotic that is used in the treatment of infections caused by susceptible microorganisms [1]. It is official in United States Pharmacopoeia, Chemically, cefoperazone sodium is 7-[R $\{2$-(4-ethyl-2,3- dioxopiperazin-1-yl carboxamide)-2-(4-hydroxylphenyl) acetamide\}-3-[1methyl-1H-tetrazol-5-yl-thiomethyl]]- 3-cephem-4-carboxilate. Its molecular formula is $\mathrm{C}_{25} \mathrm{H}_{26} \mathrm{~N}_{9} \mathrm{NaO}_{8} \mathrm{~S}_{2}$. Cefoperazone is wide spectrum and third generation of cephalosporin occupied in management of respiratory tract in addition to urinary infections [2]. Now drug interaction be capable of simply be distincted as interaction connecting a drug in addition to other substance with the intention of prevents drug commencing the stage as predictable. These connections may happen due to be short of knowledge regarding the main ingredients implicated in the related substances [3].Two medicines are antagonistic at what time their interaction occurs a reduce in special effects of one or else both of medicines. The dissimilar responses of receptor to act of a medicine has affected in number of arrangements, which use expressions such as "partial agonist", "competitive agonist" etc. This is even expected that a lot of authors would mismanage any given arrangement [4] Commonly 
iron complexes were used in convey of oxygen in human blood as well as tissues. A mature at rest takes $250 \mathrm{ml}$ of uncontaminated oxygen for each minute, these oxygens conceded by metal complex convey system recognized heame, alloying oxygen to go away the blood at what time it arrives the tissue [5].

Antibiotic and metal interaction and successfully found there after interaction result. Also, the antimicrobial activity of drug and the metals complexes were determined. This has been seen that the antibiotic interacts along with metal at the $\mathrm{pH}$ 7.4. The different essential metal intricate of the many drugs has been synthesized in addition to characterized by the techniques like NMR, UV, atomic absorption, FT-IR as well as elemental analysis. Spectroscopic, IR Spectroscopic, disk diffusion method, Biological assay studies of complexes [6]. On the other hand, in this interaction there uses metals complex which are interaction with drug into our body. And have been use their various type of bacteria for finding zone of inhibition. Some paper there uses methanol and ethanol for disk diffusion result clearly showing. Cefoperazone in a single way then it has a high bioavailability and proportionally increasing the absorption with concentration. But if we use its interaction with metals then its bioavailability and absorption decrease and less half-life [7]. By using there, a various of methods and study such as Antifungal study, Antibacterial study, Biological study with different type of spectroscopic analysis, Conductometric, IR spectrometric and Disk-diffusion methods its shows that's less pharmacological action [8]. So that after all discussion it can state that if it is taken antibiotic then it will be used the metals complex before two hours and after one hour.

\section{Materials and Methods}

Cefoperazone stock solution 250milliliter of $1 \times 10^{-2}$ Molar was ready by softening $1.386 \mathrm{gm}$ of Cefoperazone solution in the 250 milliliter of the demineralized water (DMW) in a 250 milliliter volumetric flask. The reserve solution was thinned to desired potency by the buffer solution [9] (Tables $1 \& 2$ ).

Table 1: List of chemicals and reagents.

\begin{tabular}{|c|c|c|}
\hline Serial No & Name & Source \\
\hline 1 & Cefoperazone & $\begin{array}{l}\text { Gift samples from Square } \\
\text { pharmaceuticals Ltd. }\end{array}$ \\
\hline 2 & ZincSulphate(Metal) & Merck ltd, Mumbai, India \\
\hline 3 & $\begin{array}{c}\text { Magnesium } \\
\text { Hydroxide(Antacid) }\end{array}$ & Merck ltd, Mumbai, India \\
\hline 4 & $\begin{array}{l}\text { Sodium di- } \\
\text { hydrogenphosphate }\end{array}$ & $\begin{array}{l}\text { USTC, Foys lake, Chittagong, } \\
\text { dept of pharmacy }\end{array}$ \\
\hline 5 & $\begin{array}{l}\text { Disodium hydrogen } \\
\text { phosphate }\end{array}$ & $\begin{array}{l}\text { USTC, Foys lake, Chittagong, } \\
\text { dept of pharmacy }\end{array}$ \\
\hline 6 & PhosphateBuffer & $\begin{array}{c}\text { USTC, Foys lake, Chittagong, } \\
\text { dept ofpharmacy }\end{array}$ \\
\hline
\end{tabular}

Table 2: List of instruments \&equipment's.

\begin{tabular}{|c|c|c|}
\hline Name & Model & Source \\
\hline pHMeter & $\mathrm{P}^{\mathrm{H}}-211$ & Hanna,Romania \\
\hline UVspectrophotometer & T80 & PG instrument Ltd, England \\
\hline Electronic Balance & AL-204 & Mettlertoleddo, Switzerland \\
\hline Pipette & & Fischer scientific,Germany \\
\hline
\end{tabular}

\section{Preparation of Metal Solutions}

For the grounding of 0.01 Molar metal solution like zinc sulfate heptahydrate (exactly 0.28754gm) was evaluated exactly in addition to initiated with the assist of the funnel in a $100 \mathrm{ml}$ volumetric flask, softened in DM water in addition to framework to the mark by the similar solvent. These prime solutions were additional diluted ten creases in the equivalent solvent along with the concluding solutions were $0.0001 \mathrm{M}$ concentration.

\section{Preparation of Antacid Solutions}

For the preparation of $0.01 \mathrm{M}$ antacid solution, $\operatorname{Mg}(\mathrm{OH})_{2}$ $(0.0740 \mathrm{gm})$ was evaluated accurately in addition to initiated with the facilitate of funnel in 100milliliter volumetric flask, softened in the demineralized water furthermore construct up to mark by the equal solvent. These primary solutions were further diluted ten folds in the same solvent and the final solutions were $0.0001 \mathrm{M}$ concentration [10].

\section{Grounding of the Buffer Solutions}

To get ready buffer solution 1.76gram of the disodium hydrogen phosphate were softened in the demineralized water by 2.43 gram of the solution dihydrogen phosphate in addition to $\mathrm{pH}$ was altered to 7.4 as well as volume was completed to 1000 milliliter with the equivalent solution [11].

\section{Grounding of the Typical Curve of the Cefoperazone}

Cefoperazone reserve solution at the $\mathrm{pH} 7.4$ in addition to concentration of the $1 \times 10^{-5}$ Molar was inserted in unlike concentrations to the 10 test tubes, to have subsequent concentrations like $9 \times 10^{-5}$ Molar, $8 \times 10^{-5}$ Molar, $7 \times 10^{-5}$ Molar, $6 \times 10^{-}$ 5 Molar, $5 \times 10^{-5}$ Molar, $4 \times 10^{-5}$ Molar, $3 \times 10^{-5}$ Molar, $2 \times 10^{-5}$ Molar, $1 \times 10^{-5}$ Molar. Now the solutions were suitably mixed. Then the absorbance values of solutions were established at $585 \mathrm{~nm}$ through UV spectrometer [12].

\section{Using Disc Diffusion Process}

Solution of celebrated concentration $(3 \mu \mathrm{g} / \mathrm{ml})$ of trial samples are completed through dissolving measured quantity of the trials in calculated amount of solvents. Dried in addition to sterilized filter term paper discs (6mm as a diameter) are subsequently impregnated with recognized amounts of trial substances by using micropipette. Discs holding the test substances are positioned on the nutrient agar media homogeneously seeded by the test 
organism, typical antibiotic discs along with blank discs were utilized as positive furthermore negative control. These plates now are kept at the low temperature like $4^{\circ} \mathrm{C}$ for the 24 hours to permit maximum diffusion. Throughout this time desiccated discs suck up water from surrounding medium furthermore the trial materials dissolve along with spread out of the trial disc. The diffusion happens according to physical law to controls diffusion of the molecules during agar gel. Consequently, there was a gradual alter of trial substances concentrations in medium adjoining the disc [13].

\section{Results and Discussions}

From the subsequent Table 3, this can monitor to the absorbance of the Cefoperazone enhances with the enhancing concentration in keeping with Beer Lambert's equation (Table 4). From the Table 5, it can observe that the absorbance of Cefoperazone is different when it interacts with $\mathrm{Mg}(\mathrm{OH})_{2}$. From the Table 6, it can observe that interaction between drug and metal may lead to form complexes which have different light absorption capacity and spectrum pattern is altered. So, any alteration and spectrum behavior are regarded as a tool for primary interaction from the spectral studies.

Table 3: Standard curve of Cefoperazone.

\begin{tabular}{|c|c|}
\hline Mx10 $^{-5}$ & Absorbance \\
\hline 1 & 0.472 \\
\hline 2 & 0.480 \\
\hline 3 & 0.494 \\
\hline 4 & 0.503 \\
\hline 5 & 0.516 \\
\hline 6 & 0.523 \\
\hline 7 & 0.530 \\
\hline 8 & 0.539 \\
\hline 9 & 0.544 \\
\hline
\end{tabular}

Table 4: Absorbance of Cefoperazone at different wavelength.

\begin{tabular}{|c|c|}
\hline Wavelength & Absorbance \\
\hline 200 & 0.037 \\
\hline 210 & 0.039 \\
\hline 220 & 0.33 \\
\hline 230 & 0.179 \\
\hline 240 & 0.106 \\
\hline 250 & 0.029 \\
\hline 260 & 0.034 \\
\hline 270 & 0.065 \\
\hline 280 & 0.088 \\
\hline 290 & 0.095 \\
\hline 300 & 0.125 \\
\hline 310 & 0.136 \\
\hline 320 & 0.164 \\
\hline
\end{tabular}

\begin{tabular}{|l|l|}
\hline 330 & 0.197 \\
\hline 340 & 0.216 \\
\hline
\end{tabular}

Table 5: Spectral analysis of Cefoperazone with $\mathrm{Mg}(\mathrm{OH})_{2}$.

\begin{tabular}{|c|c|c|}
\hline Wavelength/nm & $\begin{array}{c}\text { Absorbance of } \\
\text { Cefoperazone }\end{array}$ & $\begin{array}{c}\text { Absorbance of Cefoperazone } \\
\text { with } \mathbf{M g}(\mathbf{O H})_{2}\end{array}$ \\
\hline 200 & 0.037 & 0.543 \\
\hline 210 & 0.039 & 0.776 \\
\hline 220 & 0.033 & 0.662 \\
\hline 230 & 0.179 & 0.323 \\
\hline 240 & 0.106 & 0.182 \\
\hline 250 & 0.029 & 0.092 \\
\hline 260 & 0.034 & 0.135 \\
\hline 270 & 0.065 & 0.147 \\
\hline 280 & 0.088 & 0.169 \\
\hline 290 & 0.095 & 0.178 \\
\hline 300 & 0.125 & 0.189 \\
\hline 310 & 0.136 & 0.193 \\
\hline 320 & 0.164 & 0.198 \\
\hline 330 & 0.197 & 0.214 \\
\hline 340 & 0.216 & 0.219 \\
\hline
\end{tabular}

Table 6: Combined Spectral analysis of Cefoperazone with $\mathrm{ZnSO}_{4} \cdot 7 \mathrm{H}_{2} \mathrm{O}$

\begin{tabular}{|c|c|c|}
\hline Wavelength/nm & $\begin{array}{c}\text { Absorbance of } \\
\text { Cefoperazone }\end{array}$ & $\begin{array}{c}\text { Absorbance of Cefoperazone } \\
\text { with } \mathbf{Z n S O}_{\mathbf{4}} \cdot \mathbf{7 H}_{\mathbf{2}} \mathbf{0}\end{array}$ \\
\hline 200 & 0.037 & 0.342 \\
\hline 210 & 0.039 & 0.675 \\
\hline 220 & 0.033 & 0.561 \\
\hline 230 & 0.179 & 0.222 \\
\hline 240 & 0.106 & 0.081 \\
\hline 250 & 0.029 & 0.091 \\
\hline 260 & 0.034 & 0.104 \\
\hline 270 & 0.065 & 0.116 \\
\hline 280 & 0.088 & 0.130 \\
\hline 290 & 0.095 & 0.147 \\
\hline 300 & 0.125 & 0.159 \\
\hline 310 & 0.136 & 0.163 \\
\hline 320 & 0.164 & 0.170 \\
\hline 330 & 0.197 & 0.184 \\
\hline 340 & 0.216 & 0.203 \\
\hline
\end{tabular}

Outcome of the Metals on Cefoperazone by Job's Technique of Incessant Variation:

The molar proportions of complexes of the Cefoperazone by metal salt were calculated approximately through Job's method. The examined absorbance rates were calculated in the $\mathrm{pH} 7.4$ at diverse concentration like $1 \times 10^{-5}$ to $9 \times 10^{-5}$ Molar of Cefoperazone by metal salt. Then Job's plots at the $\mathrm{pH}$ were acquired through plotting absorbance variation against mole portion of drug (Table 
7). From the above we can observe that Cefoperazone forms strong 1:1 complex with zinc sulfate heptahydrate which is indicated as inverted ' $V$ ' shaped curve. From the above we can observe that

Table 7: Values of job's plot of Cefoperazone with $\mathrm{ZnSO}_{4} \cdot 7 \mathrm{H}_{2} \mathrm{O}$.
Cefoperazone forms strong 1:1 complex with $\mathrm{Mg}(\mathrm{OH})_{2}$ which is indicated as inverted ' $v$ ' shaped curve (Table 8).

\begin{tabular}{|c|c|c|c|c|c|}
\hline $\begin{array}{l}\text { Concentration } \\
\text { of Cefoperazone } \\
\text { Mx10 }^{-5}\end{array}$ & $\begin{array}{c}\text { Absorbance of } \\
\text { Cefoperazone } \\
\text { A }\end{array}$ & $\begin{array}{c}\text { Concentration of } \\
\mathrm{ZnSO}_{4} \cdot 7 \mathrm{H}_{2} \mathrm{O} \\
\mathrm{Mx}^{-5}\end{array}$ & $\begin{array}{c}\text { Absorbance of } \\
\mathrm{ZnSO}_{4} \cdot 7 \mathrm{H}_{2} \mathrm{O} \\
\text { B }\end{array}$ & $\begin{array}{c}\text { Absorbance of } \\
\text { mixture } \\
\text { C }\end{array}$ & $\begin{array}{c}\begin{array}{c}\text { Absorbance } \\
\text { difference }\end{array} \\
D=(A+B)-C\end{array}$ \\
\hline 1 & 0.472 & 9 & 0.187 & 0.110 & 0.549 \\
\hline 2 & 0.480 & 8 & 0.186 & 0.109 & 0.557 \\
\hline 3 & 0.494 & 7 & 0.187 & 0.109 & 0.572 \\
\hline 4 & 0.503 & 6 & 0.188 & 0.112 & 0.579 \\
\hline 5 & 0.516 & 5 & 0.189 & 0.111 & 0.594 \\
\hline 6 & 0.523 & 4 & 0.192 & 0.128 & 0.587 \\
\hline 7 & 0.530 & 3 & 0.181 & 0.125 & 0.586 \\
\hline 8 & 0.539 & 2 & 0.179 & 0.136 & 0.582 \\
\hline 9 & 0.544 & 1 & 0.177 & 0.150 & 0.571 \\
\hline
\end{tabular}

Table 8: Values of Job plot of Cefoperazone and $\mathrm{Mg}(\mathrm{OH})_{2}$.

\begin{tabular}{|c|c|c|c|c|c|}
\hline $\begin{array}{l}\text { Concentration of } \\
\text { Cefoperazone } \\
\text { Mx10 }^{-5}\end{array}$ & $\begin{array}{c}\text { Absorbance } \\
\text { of Cefoperazone } \\
\text { A }\end{array}$ & $\begin{array}{l}\text { Concentration of } \\
\operatorname{Mg}(\mathrm{OH})_{2} \\
\mathrm{Mx10^{-5 }}\end{array}$ & $\begin{array}{c}\text { Absorbance of } \\
\operatorname{Mg}(\mathrm{OH})_{2} \\
\text { B }\end{array}$ & $\begin{array}{l}\text { Absorbance difference } \\
\qquad D=(A+B)-C\end{array}$ & $\begin{array}{l}\text { Absorbance difference } \\
\qquad D=(A+B)-C\end{array}$ \\
\hline 1 & 0.472 & 9 & 0.090 & 0.114 & 0.448 \\
\hline 2 & 0.480 & 8 & 0.086 & 0.112 & 0.454 \\
\hline 3 & 0.494 & 7 & 0.093 & 0.118 & 0.469 \\
\hline 4 & 0.503 & 6 & 0.096 & 0.118 & 0.481 \\
\hline 5 & 0.516 & 5 & 0.103 & 0.120 & 0.499 \\
\hline 6 & 0.523 & 4 & 0.097 & 0.132 & 0.488 \\
\hline 7 & 0.530 & 3 & 0.092 & 0.136 & 0.486 \\
\hline 8 & 0.539 & 2 & 0.085 & 0.147 & 0.477 \\
\hline 9 & 0.544 & 1 & 0.083 & 0.162 & 0.465 \\
\hline
\end{tabular}

\section{Antimicrobial Reading}

The antimicrobial effectiveness of the trial agents is calculated by their action to avoid the enlargement of microorganisms neighboring discs which provides clear precinct of inhibition. Later than incubation, the antimicrobial actions of the trial materials were concluded through measuring diameter of zones of the inhibition inside millimeter through a crystal-clear mm scale (Table 9). The trial samples were examined in opposition to Staphylococcus aureus. The typical Cefoperazone disk also checked in opposition to Staphylococcus aureus. The consequences of the antimicrobial action calculated in view of diameter of the zone of the inhibition in the $\mathrm{mm}$ were demonstrated in Table 10. Antimicrobial sensitivity testing of Cefoperazone against Staphylococcus aureus after interacting with $\mathrm{ZnSO}_{4} \cdot 7 \mathrm{H}_{2} \mathrm{O}$ and $\mathrm{Mg}(\mathrm{OH})_{2}$ solution, respectively. Now it was proved that zone of the inhibition of the Cefoperazone through Metal and antacid $\mathrm{Zn}, \mathrm{Mg}$ reduced from $16 \mathrm{~mm}$ to $14 \mathrm{~mm}$
\& $13 \mathrm{~mm}$ correspondingly due to the metal, antacid and drug interaction.

Table 9: Combined absorbance of drug with different metal \& antacid.

\begin{tabular}{|c|c|c|}
\hline Cefoperazone & $\begin{array}{c}\text { Cefoperazone with } \\
\mathbf{Z n S O}_{\mathbf{4}} \mathbf{. 7} \mathbf{H}_{\mathbf{2}} \mathbf{0}\end{array}$ & $\begin{array}{c}\text { Cefoperazone with } \\
\mathbf{M g}\left(\mathbf{O H} \mathbf{~}_{\mathbf{2}}\right.\end{array}$ \\
\hline 0.472 & 0.187 & 0.090 \\
\hline 0.480 & 0.186 & 0.086 \\
\hline 0.494 & 0.187 & 0.093 \\
\hline 0.503 & 0.188 & 0.096 \\
\hline 0.516 & 0.189 & 0.103 \\
\hline 0.523 & 0.192 & 0.097 \\
\hline 0.530 & 0.181 & 0.092 \\
\hline 0.539 & 0.179 & 0.085 \\
\hline 0.544 & 0.177 & 0.083 \\
\hline
\end{tabular}


Table 10: Diameter of zone of inhibition.

\begin{tabular}{|c|c|c|}
\hline Bacteria used & $\begin{array}{c}\text { Standard disk (zone of } \\
\text { inhibition/mm) }\end{array}$ & $\begin{array}{c}\text { Sample disk (zone of } \\
\text { inhibition) }\end{array}$ \\
\hline \multirow{2}{*}{$\begin{array}{c}\text { Staphylococcus } \\
\text { aureus }\end{array}$} & $16 \mathrm{~mm}$ & $\begin{array}{c}\text { Cefoperazone }+ \\
\mathrm{ZnSO}_{4} \cdot 7 \mathrm{H}_{2} \mathrm{O}\end{array}$ \\
\cline { 2 - 3 } $\begin{array}{c}\text { Staphylococcus } \\
\text { aureus }\end{array}$ & $16 \mathrm{~mm}$ & $14 \mathrm{~mm}$ \\
\cline { 2 - 3 } & & $\begin{array}{c}\text { Cefoperazone with } \\
\mathrm{Mg}(\mathrm{OH})_{2}\end{array}$ \\
\cline { 2 - 3 } & & $13 \mathrm{~mm}$ \\
\hline
\end{tabular}

\section{Conclusion}

Though, there were some limitations in this research work like proper financial support from any side, active pure drug collection was not easy in Bangladesh. Eventually it has been overcome. The sophisticated spectrophotometric technique is easy, straight as well as worthwhile for the fortitude of drug. Commencing this spectral reading, this has been observed that Cefoperazone provides a spiky peak at the $585 \mathrm{~nm}$. At what time Zinc Sulfate furthermore antacid solution, $\mathrm{Mg}(\mathrm{OH})_{2}$ combined with Cefoperazone 1:1 ratio and the strength of peak alters extremely and absorption features are changed due to the interaction although the position of complex do notchange. Then antimicrobial viewing of a mediator is crucial to find out its spectrum in opposition to various natures of the pathogenic microorganisms. The Job's plot has provided the molar percentage of the complexes of Cefoperazone through Zinc Sulfate in addition to antacid solution like $\mathrm{Mg}(\mathrm{OH})_{2}$. At the $\mathrm{pH} 7.4$ Cefoperazone structures tough 1:1 complex through Zinc Sulfate in addition to antacid solution like $\mathrm{Mg}(\mathrm{OH})_{2}$ designated as ' $\wedge$ ' natured curves. These curves can indicate well-built kinetics of the complexation between Cefoperazone by Zinc Sulfate along with antacid solution like magnesium hydroxide. The trial samples were checked in opposition to Staphylococcus aureus. The typical Cefoperazone disk also checked in opposition to Staphylococcus aureus. It was examined that antimicrobial action of the Cefoperazone reduces when it structures complexes through $\mathrm{ZnSO}_{4} \cdot 7 \mathrm{H}_{2} \mathrm{O}$ in addition to antacid solution like magnesium hydroxide. Thus, through antimicrobial examination it was proved that zone of the inhibition of the Cefoperazone through Metal and antacid $\mathrm{Zn}, \mathrm{Mg}$ reduced from $16 \mathrm{~mm}$ to $14 \mathrm{~mm} \& 13 \mathrm{~mm}$ correspondingly.

ISSN: 2574-1241

DOI: 10.26717/BJSTR.2020.31.005081

Joushan Ara. Biomed J Sci \& Tech Res

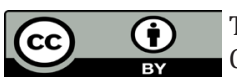

This work is licensed under Creative Commons Attribution 4.0 License

Submission Link: https://biomedres.us/submit-manuscript.php

\section{References}

1. Narasimhamurthy LN, Basaya PS, Pai, Sanjay PN (2009) A StabilityIndicating HPLC Method for determination of Cefoperazone. Eurasian Journal of Analytical Chemistry 4(1): 10-18.

2. Parra A, Garcia-Villanova J, Rodenas V, Gomez MD (1994) First and second derivative spectrophotometric determination of cefoperazone and sulbactam in injections. Journal of Pharmaceutical and Biomedical Analysis 12(5): 653-657.

3. Ratna Kumari K, Devala Rao G (2010) New Spectrophotometric Methods for the Determination of Cefoperazone in Pharmaceutical Formulation. International Journal of Pharmaceutical Research andDevelopedment 2(1): $1-5$.

4. Saleh GA, Askal HF, Radwan MF, Omar MA (2001) Use of chargetransfer complexation in the spectrophotometric analysis of certain cephalosporins. Talanta 54(6): 1205-1215.

5. El-Azazy MS, Shalaby A, EL-Bolkiny MN, Khalil HM (2003) Spectrophotometric determination of cefepime hydrochloridehydrochloride, cefoperazone $\mathrm{Na}$, ceftazidimepentahydrate, cefuroxime sodium and etamsylate using ammonium molybdate. Sci Pharm 71(3): 211-228.

6. S Koppisett V, Chandra N (2011) Influence of Alcohol and Smoking on Drug Action: A Step for better utilization of drugs. Journal of Chemical and Pharmaceutical Research 3(1): 242-248.

7. Chou TC (2006) Theoretical basis, experimental design, and computerized simulation of synergism and antagonism in drug combination studies. Pharmacological reviews 58(3): 621-681.

8. C Sadowski D (2012) Drug Interactions with Antacids Mechanisms and Clinical Significance. springer international journal 11(6): 395-407.

9. Tallarida RJ (2001) Drug synergism: its detection and applications. Journal of Pharmacology and Experimental Therapeutics 298(3): 865872.

10. Aronson JK (2004) Drug interactions-information, education, and the British National Formulary. British Journal of Clinical Pharmacology 57: 371-372.

11. Sanket P, Satish P (2011) Dual wavelength spectrophotometric method for simultaneous estimation of ofloxacin and cefpodoximeproxetil in tablet dosage form. Asian J Pharm Life Sci 1(3): 261-268.

12. Patil V, Chaudari RY (2012) Spectrophotometric method for estimation of cefpodoximeproxetil and ofloxacin in tablet dosage form by simultaneous equation method. Int J Pharm Life Sci 3(9): 1982-1984.

13. Billov S, Kizek R, Jelen F, Novotn P (2003) Square-wavevoltammetric determination of cefoperazone in abacterial culture, pharmaceutical drug, milk, and urine. Analytical and Bioanalytical Chemistry 377(2): 362-369.

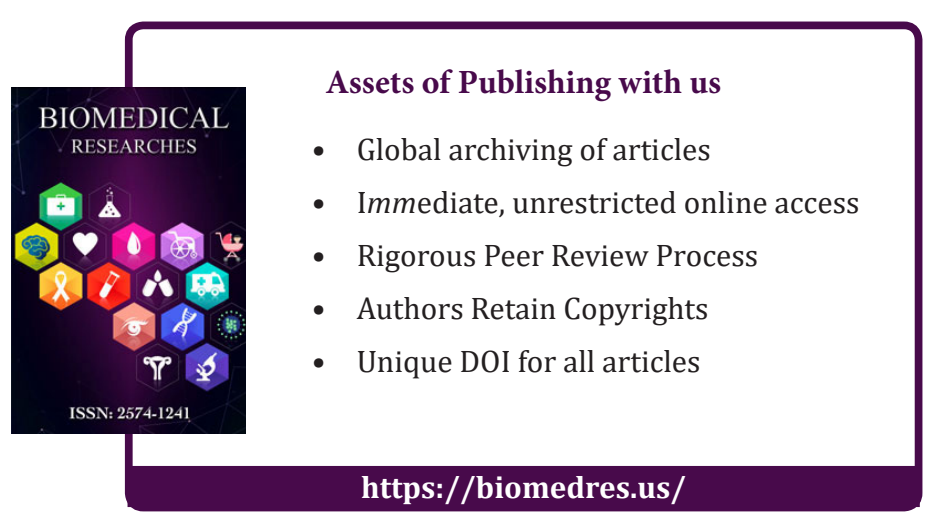

